International Research Journal of Engineering, IT \& Scientific Research
Available online at https://sloap.org/journals/index.php/irjeis/
Vol. 4 No. 4, July 2018, pages: $30 \sim 39$
ISSN: 2454-2261
https://sloap.org/journals/index.php/irjeis/article/view/259

\title{
Arm Muscle Power and Energy System Measurement of Forehand Drive on Tennis
}

La Sawali a

\section{Article history:}

Received: 14 February 2018

Revised: 10 June 2018

Approved: 27 June 2018

Published: 11 July 2018

\section{Keywords:}

Tennis;

Measurement;

Muscle Power;

Energy System;

Forehand Drive;

\begin{abstract}
This study analyzed arm muscle power and energy system measurements that work during a forehand drive on tennis. The strength of the arm and energy system information is known to be processed through several stages, i.e. identification of stimuli, the response selection stage, and the programming stage to the giving instruction of muscle movement. In this case, the player's forehand driveability increased by the strategy of drills forehand flat and forehand topspin training. Exercises are given to both of group whose having similar the strong arm and the weak arm. Qualitative descriptions for measuring forehand drive strokes achievement are conducted to explain the strength of the arm using instrument that has been tested for its validity. This is done by troughs observing each stage treatment type of activities in the implementation of an exercise strategy which tailored the emotion process as a supporter of ability at doing forehand drive. The instruments used to see forehand driveability are designed and developed by the author himself by taking the factors of difficulties and skills possessed, then it is used as the subject of this study. The created instruments refer to the standardized of Hewitt's achievement test instrument presented by Jack E. Hewitt's, which uses numbers from 1 to 5 . Furthermore, to do the measures of power for looking the energy systems is exerted by the Estimated Maximum Power Output and Capacity of Three Energy Systems table by Fox et al.
\end{abstract}

2454-2261 ${ }^{\circledR}$ Copyright 2018. The Author. This is an open-access article under the CC BY-SA license (https://creativecommons.org/licenses/by-sa/4.0/) All rights reserved.

\section{Author correspondence:}

La Sawali,

Lecturer at Physical Education Dept. of Education Faculty of Halu Oleo University

Kendari, Southeast Sulawesi-Indonesia 93232,

Email address: sawali_la@yahoo.co.id

\section{Introduction}

An individual exercise in a sport is essentially a process of bodybuilding to improve physical condition and skills in the long run. Exercise is a systematic process of practicing or working, which is repeated over time by increasing the amount of workload or its workload. Exercise is an effort that is generally led, organized, and planned by a

a Lecturer at Physical Education Dept. of Education Faculty of Halu Oleo University, Kendari, Southeast Sulawesi, Indonesia 93232 
trainer. In this line, the trainer has a very big role, and not just as a trainer or educator but his task also is very complex. He must have supporting knowledge such as physiology, psychology, social, and training are all things to the profession as coach and athletes as well (see Sawali, 2018).

In the process of learning motion skills on tennis is essentially different from cognitive and effective learning. In tennis, the dominant aspect depends on movement skills of physical and psychomotor. There are three stages to the process of learning motion skills, i.e. (1) cognitive stage, (2) the associative stage, and (3) autonomous stage.

In the cognitive stage occurs the process of information processing. The occurrences of the learning process of motion are because of the external stimuli received by the sense of sight, hearing, and kinesthetic sense. Furthermore, the senses are passed on to the central nervous system to be processed, interpreted, and stored in shortterm memory, then entered on long-term storage and then translated in motion format. In the associative stage, the actualization of movement is achieved through explanations and demonstrations of teacher or trainer. The mastery of movement on this stage has been able to perform movements in the format of uninterrupted series. Then in the autonomous learning stage, there is a pattern of time spaces that have been embedded in process of automation of movement. This stage is characterized by the ability of the athlete to do the movement automatically without being affected by other things. At this stage, automation has occurred to be a process of information without any interruption from the cognitive stage (processing stage of the existing stimuli). The movements that occur in this automation become smoother, more consistent, and more stable.

The motion control system for the formation of a movement can take advantage of feedback from body components respond, which is done to spur final activities of muscle and the begin of other muscle activities. Referring to the idea of motion control, there is centrally organized of structure that is not only capable to dealing with detailed of actions but also very sensitive to sensory information that evokes responses from various sources in the human body.

According to Schmidt (1991), there are two systems in movement learning to control of motion, namely (1) closed-loop control, and (2) open loop control. In the motion control of closed-loop control includes processing of feedback it is matched with the aright or fault hitting motion of forehand drive reference, so by the basis of an error that occurred improvement can be done immediately. In another side, Schmidt emphasized that closed-loop control is relevant for movements performed in a slow and dynamic tempo and required high accuracy. Then, the open loop control according to Schmidt is more appropriate for fast movements. Thus, the repetitive stages exercise to get movement automation becomes more stable and consistent.

In the line with described above, Sawali (2018, p.12) stated that the forehand drive in tennis is divided into two types, namely forehand flat and forehand topspin lobs. The forehand flat is a pitch on tennis that starts from the racket swing backward at the position between waist and shoulder with a ball in high speed, a flat ball direction, and a slight spin. Whereas forehand topspin is a lob, that is carried out until the ball stroke forward at high speed (turning very high speed). When a player does strike by forehand topspin the rotate of ball direction forward and swoop down, the air resistances greater in the upper center of the ball (compare to Magheti, 1990).

This study analyzed the arm muscle power and energy system measurement during forehand drive stroke on tennis. The information about the strength of arm and energy system is known to be processed through several stages, i.e. identification of stimuli, the response selection stage, and the programming stage to the giving instruction of muscle movement. If doing a movement, then every athlete must have a referral, how the movement was right or wrong. This is very important because it will be used as a benchmark or standard for reassessing the implementation of motion. The results of the comparison between referrals and appearances of motion will be assessed in the format of feedback.

Absolutely, strength exercises are given almost from all sports, even it should be given earliest before the other elements. Farisa, Nyak Amir, \& Muhammad Jafar, (2017: p.107) stated, the way to increase of power is with resistance (resistance-Training or called RT). In line with this, Codero and Mikel Izquierdo (2017: p. 2) said, the sets using explosive muscle action can be performed alone or combined with traditional RT (i.e. slow concentric muscle action) during the training organization, but always avoiding concentric failure. Codero and Mikel Izquierdo added that the training intensity should range from $30 \%$ to $60 \%$ of intensity resistance of muscle (IRM) load because maximal power output is maximized at these intensities. With increasing exercise, the strength of arm muscle becomes one of the most important physical components in learning the basic techniques of tennis.

Sawali, L. (2018). Arm muscle power and energy system measurement of forehand drive on tennis. International Research Journal of Engineering, IT \& Scientific Research, 4(4), 30-39. https://doi.org/10.21744/irjeis.v4n4.259 


\section{Research Methods}

This study was explored through observations of internal and external validity controls in energy system and arm muscle movement during forehand drive stroke. In this case, the ability increased of a forehand drive stroke of tennis given to the player who has exercised by using drills forehand flat and forehand topspin strategies. Where the exercises are given to the group whose having the similar strong arm and weak arm.

Qualitative descriptions for measuring the achievement of forehand drive strokes on tennis are conducted to explain the measurement strength of the arm which using an instrument that has been tested for its validity. The observing each stage type of treatment activities in exercise application strategy tailored to the process of motion, which can support the improvement of athlete achievement at doing forehand drive strokes. As for, the instrument used to see the ability of the forehand drive is an instrument that designed and developed by the researcher himself by taking the factors of difficulty and skills possessed by an athlete. Then, that is used as a subject in this study. The developed instrument refers to standardized of Hewitt's achievement test instrument presented by Jack E. Hewitt's, which uses numbers from 1 to 5 (Basco and William F. Gustafson, 1983: p.217). The prediction of the ability of a forehand drive stroke on tennis can be seen in Table 1 below:

Table 1

Stroke Achievement Prediction of Forehand Drive by Hewitt's

\begin{tabular}{ccc}
\hline Construct & \multicolumn{1}{c}{ Indicator } & Assessment \\
\hline $\begin{array}{c}\text { The ability of Forehand drive } \\
\text { stroke }\end{array}$ & $\begin{array}{l}\text { (a) Value of precision } \\
\text { (b) Value of Strength }\end{array}$ & Total of Indicator (a) + Indicator (b) \\
\hline
\end{tabular}

Furthermore, at doing measures of power in looking the energy systems are using Capacity and Maximum Power of Three Energy Systems by Fox et al. table.

\section{Results and Analysis}

\subsection{Arm Muscle Power of Forehand Drive}

Conventionally, muscle strength is one of a very important components to improve overall physical condition, these components are based on three reasons: a) because the power is the driving force of every physical activity, b) because the power plays a very important role in athlete protecting from the possibility of injury, c) because with strength, the athlete will be able to hit, run, throw or kick farther and efficiently, thereby also helping the stability of the joint (Sharkey, 1984: p.55).

The human body is made up of a lot of muscle tissue, each having a certain function in everyday life. Mostly the muscle structure is a large unity and forming human body weight.

The need to maximize strength is also particular importance for many athletes, as the capacity to produce near maximal forces is required in sport (Schoendfield, et al., 2015). In this case, arm muscle strength is a component of the physical condition that concerns to the ability of athlete when using arm muscles, which is accepting a load at a particular time (Sajoto, 1987: p.198).

In tennis, the arm strength is very important, because at doing a hit will affect to the hardness and precisely of the ball in accordance with the target. As for, the strength is obtained from a group of muscular and their magnitude on the wide cross-section of muscles as well. Therefore, the tennis athletes are encouraged to train the muscle strength of their arms in order to hit well and correctly. Basically, the arm muscle is used to do the punch, when the arms swing at the punch moment it will put pressure on the ball to be hit (Miller, 2010).

The muscular structure of arm is essentially composed of two components, each composed of a thick protein material called the filamen myosin and a thin protein material called filamen actin. Both are interconnected with a muscle binding materials called cross bridge. The bonding of filamen actin, filamen myosin, and cross bridge are the smallest unit that is the cause of muscle contraction and this smallest bond is called sarcomere.

Fox (1993: p.231) stated that skeletal muscle fibers consist of two types of slow twitch fiber and fast twitch fiber. Slow twitch fiber was a red color that works to aerobically, whereas fast twitch fiber was white color, which works to anaerobically. Fast twitch fiber was white because it more creatine phosphate (CP) contains. This muscle has 
more reticulum sarcoplasmic than slow twitch fiber, so the release of calcium ions be faster and also quickly to recognized the calcium ions. In the line with this, the process of supply through anaerobic and the available of energy will quickly run out by it a faster contraction.

The arm muscles referred to in this study are anatomically composed of biceps humerus, triceps, carpi radialis, carpi ulnaris, and deltoideus (Budiyono S., 2011: p.9). For more details can be seen in the figures below:
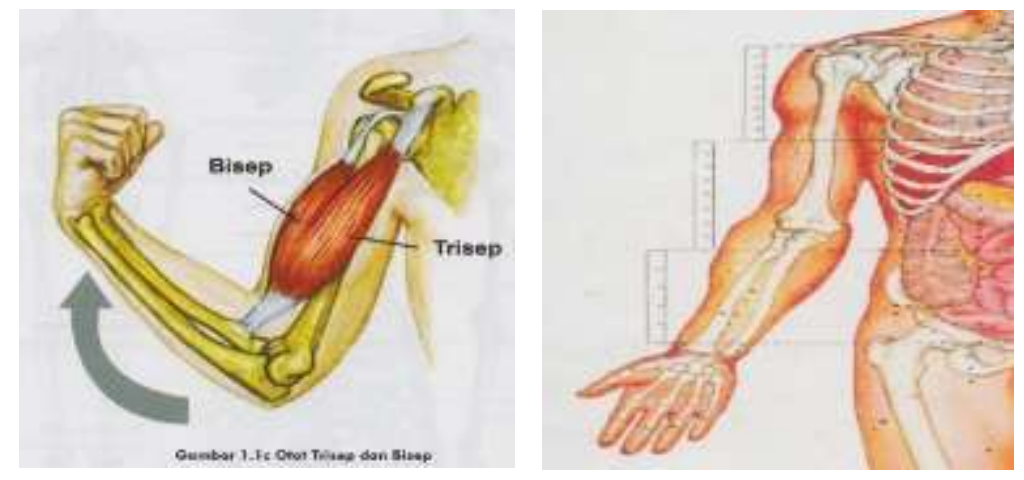

Figure 1. Arm Muscles

Arm strength is needed in performing movements such as throwing, hitting, pushing, lifting and pulling. These movements are aroused by muscle contraction to all directions in the $360^{\circ}$ range. Anatomically these movements are 1) flexion, 2) extension, 3) abduction, 4) posterior abduction, 5) horizontal abduction, 6) lateral rotation, and 7) medium rotation (Pate and Robert Rotella 1993: p.151).

A forehand drive movement on tennis is an anatomically combined of posterior extension-abduction movement. At doing forehand drive, the most contracting muscle focused in arm muscle because the arm function holds the racket. The ball that was hit by full power will produce faster and sharper ball motion. Thus the arm muscle strength was very important to a forehand drive stroke.

In accordance with the nature and form of motion in sport, the strength is divided into two terms, i.e. cyclic power and acyclic power (Bompa, 2009: p.280). Cyclic power is required in sports that require sprinting speed in athletics and swimming. The recommended exercise dose requires 30-50\% workload and maximum ability, the motion rhythm is very dynamic as much as 10 repeats with 5 minutes rest interval. While the power of acyclic is a powerful and fast movement such as throwing, jumping, jumping, fencing, diving, and all types of sports that require shot put, such as volleyball, basketball, and tennis. The recommended dose of exercise requires 50-80\% workload, the rhythm of the movement is done very quickly, the interval between 3-5 minutes.

The muscle fibers structure influences of skeletal muscle, fast twitch fiber and slow twitch fiber, connective tissue, tissue elasticity, endocrine, energy transfer efficiency, development and growth of myofibrils and motor unit deployment those also affected to the strengthening of the arm at doing a variety of a hit.

For tennis, there are some athletes whose have weak arm strength but better on forehand topspin compared with the athletes on forehand flat.

Setyobroto (2001) stated that in a particular sport an athlete becomes a champion is not only need strong muscle or physical strength but the ingenious mind will determine the winning moment in the competition.

Furthermore, Fox et al. (1993: p.157) stated that strength is influenced by several factors, namely: (1) the anatomical and physiological aspects which include: (a) the type of skeletal muscle fiber, (b) the skeletal muscle area, (c) the number of cross-bridges involved, (2) ), the physiological biochemical aspects of energy metabolism, especially anaerobic metabolism, and (3) kinesiological biomechanical aspects includes: (a) the joint angle, (b) the velocity, and (c) the interaction of positions between the body parts and the mechanical system of total energy.

In tennis, the energy system used to produce strength in the arm muscle at doing a drive. The strength of the ball accelerate resulting depends on the power of arm muscle. As for, the measurement of an athlete's arm strength during forehand can be known through the instrument refers to standardized Hewitt's achievement test. The description of the court to achievement test can be seen as figure 2 . below:

Sawali, L. (2018). Arm muscle power and energy system measurement of forehand drive on tennis. International Research Journal of Engineering, IT \& Scientific Research, 4(4), 30-39. https://doi.org/10.21744/irjeis.v4n4.259 


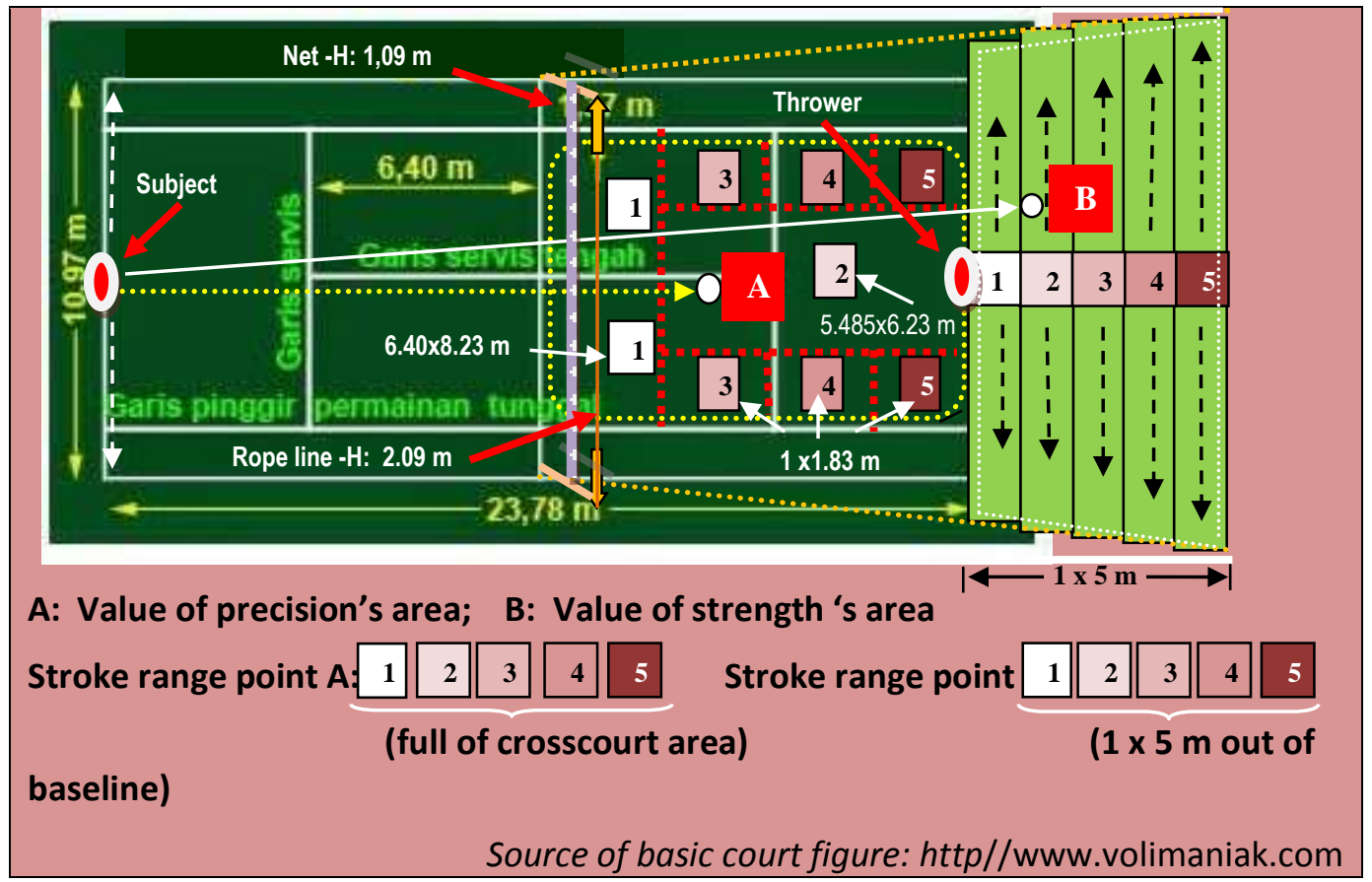

Figure 2. Tennis Court Description

to Stroke Achievement Prediction Test of Forehand Drive

(Court Figure Modification of Hewitt's' Test Redesigned by Lindayani*)

The forehand drive achievement on tennis is the hitting ability with the ball hitting position on the right side for the right hand's racket holder or vice versa. The position of the body and knees slightly bent, so the weight slightly forward. Thus, at doing a forehand drive the player can control the ball maximally.

The measurement of forehand drive stroke achievement of athlete (subject) is obtained through the score of point and value from the maximum results made by the subject at doing forehand. Where the subject initial position is standing at the center of baseline, thereafter a thrower catapults ball crossing of the net, and the ball will be hit by the subject with target point and value shown on the tennis court as illustrated at figure (2).

The subject gained ten times chances to do strokes, each ball of forehand must pass between net and rope line. The rope line stretched one meter over the net and subject struck the ball to opponent court area which already shown scores position. Ranging of the scores are $1-5$ for point and $1-5$ for value, and the highest result is 100 (number of points and values), and the lowest value is 0 (love). The forehand drive accuracy measurement of the subject is obtained by the ball shots into target area (A area) as well as the distance of ball reflections between the first bounce up to the second bounce. Whereas the accuracy of ball precision accordance the numbers are shown on tennis court area (B area), if the ball position is on the line between two points positions, and the result of point score should be taken from the highest precision point. And if the subject hits the ball over of rope then the ball is considered out, it was no point or 0 (love). The 100 score obtained due all the balls are struck between net and rope, as well as the ball accuracy reached on target which motioned point 5 and the ball bounce distance reached out of baseline at point 5 part on the tennis court as well.

\subsection{Energy System}

The strength is the essence of a sport that has a long duration. It needs energy power. There is an energy system in the muscles of the human body. Energy system which used to produce power is called ATP-PC or phosphagen energy system. As the name suggests the ATP-PC system consists of adenosine triphosphate (ATP) and phosphocreatine. Phosphagen (ATP-PC) energy system involved in the anaerobic mechanism, Phosphagen is stored

* Lindayani, Lilik Rita, Lecturer of Language and Literature Department of Halu Oleo University 
very small in the muscle, and the glycogen or glucose stored in the muscle that broken down into lactic acid to create it. Lactic acid systems will occur after the backup of phosphagen exhausted, or the exercise is done up during rest two minutes. Fox said, there are 3 processes in producing ATP, i.e. the ATP-PC system or ATP-DC system, an anaerobic glycolysis system or a lactic acid system, and an oxygen system or aerobic system.

Table 2

Estimated Maximum Power Output and Capacity of Three Energy Systems by Fox et al.

\begin{tabular}{ccc}
\hline Sistem Energy & $\begin{array}{c}\text { Maximal Power (Moles of ATP } \\
\text { per Minute) }\end{array}$ & $\begin{array}{c}\text { Maximal Capacity (Total Moles } \\
\text { ATP available) }\end{array}$ \\
\hline Phosphagen (ATP-PC) & 3.6 & 0.7 \\
Anaerobic Glycolisis (Lactid acid) & 1.6 & 1.2 \\
Aerobic or Oxygen (from glycogen & 1.0 & 90.0 \\
only) & & 9 \\
\hline
\end{tabular}

Conventionally, there are three energy systems that produce muscle contraction, namely: 1) phosphagen system (ATP-PC) (high power, short duration) 2) lactic acid system (moderate power, short duration), and 3) Aerobic system (low power, long duration). To develop this energy system, the approximately to rest between repeats to allow replenish system is the sessions involving repeats of up to 10-15 seconds of maximum intensity activity/work are required. Of the three systems are classified, anaerobic systems divided into two systems namely ATP-PC and lactic acid systems. Both systems used in sports activities that require strength, as shown in Table 2.

1) ATP-PC (Phosphagen) System

a. ATP (Adenosine Tri-Phosphate) system

The energy of this system is obtained from ATP-PC. ATP is a high-energy phosphate compound, but the supply in the muscle is very limited. Therefore, in order for the muscles reform quickly, the ATP must be retrieved. To reconstruct the ATP needed chemical compounds that exist in the muscle. These compounds are $\mathrm{PC}$, if the $\mathrm{PC}$ explosive, the energy will provide immediately. To make ATP, PC transfers a phosphate molecule to adenosine diphosphate (ADP). The newly formed ATP is now available to be used to muscle contraction. The breakdown process is as follows:

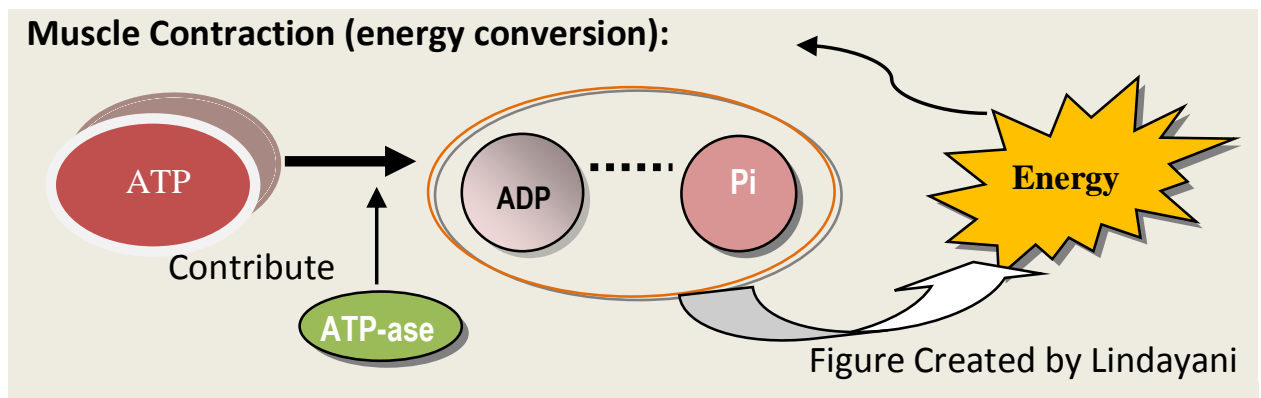

Figure 3. ATP (Adenosine Triphospate) System

b. PC (Phosphocreatine) System

Muscle fatigue is noticeable by the end of the phosphocreatine cycle. ATP and PC are stored in muscle. Both of them contain phosphate systems, ATP and PC will dispense the phosphate group when producing energy. The end result of PC splitting process is creatine $(\mathrm{C})$ and inorganic phospho (Pi).

The PC-breaking process is aided by the creatine kinase enzyme. This process goes on forever in play (each to $5-8$ seconds) as long as supplies are still sufficient to reform ATP. The ATP-PC system is a rapid source of energy that can be provided for muscle contraction. By this condition, some of the reasons for the supply speed of energy sources and the ATP-PC system are described as follows: (1) the formation of ATP is the independent series of long chemical reactions, (2) the formation of ATP is the independent of oxygen

Sawali, L. (2018). Arm muscle power and energy system measurement of forehand drive on tennis. International Research Journal of Engineering, IT \& Scientific Research, 4(4), 30-39. https://doi.org/10.21744/irjeis.v4n4.259 
transport from outside of human body, and (3) ATP and PC are stored in muscle contraction mechanism directly.

By the explained above that the ATP-PC supplies are limited. Therefore, to carry out heavier and longer activities required the process of re-forming ATP through another energy system that is called the PC system. The breakdown process of PC shown in Figure 4 below:

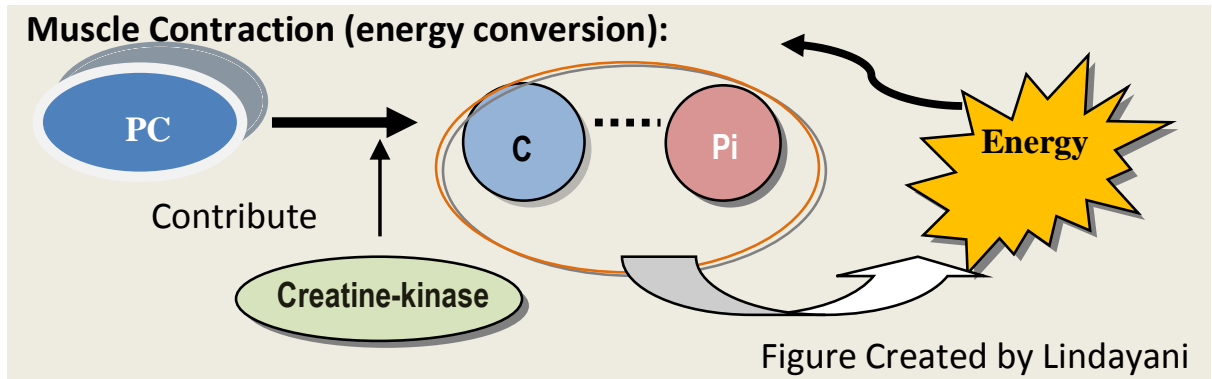

Figure 4. PC (Phosphocreatine) System

2) Lactic Acid System

The lactic acid system is a system of energy supply from the burning of fuel reserves in muscles and liver. The fuel reserve was glycogen. In this system, the energy released is used for the replenishment of ATP. Because of this work independent of oxygen, only a portion of the glucose can be produced and partly produced by lactic acid. When lactic acid is buried in large quantities in blood, it will be the cause of fatigue. The chemical reactions of ATP glycolysis formation can be described as follows:

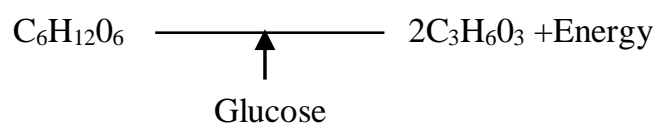

The energy released is used for replenishment of ATP.

Energy + ADP + 3Pi+ ATP

Each reaction requires the presence of a special enzyme as a regulator of reaction velocity viz. phosphofructokinase enzyme (PFK). Only a few recombinant ATP molecules can be reformed from glycogen during the anaerobic glycolysis process. During the anaerobic glycolysis process, only three molecules of ATP are reformed from the decomposition of one ATP molecule employed in anaerobic glycolysis. In this case, during exercise muscles and blood should be able to accept 60-70 grams of Lactic acid before the onset of fatigue.

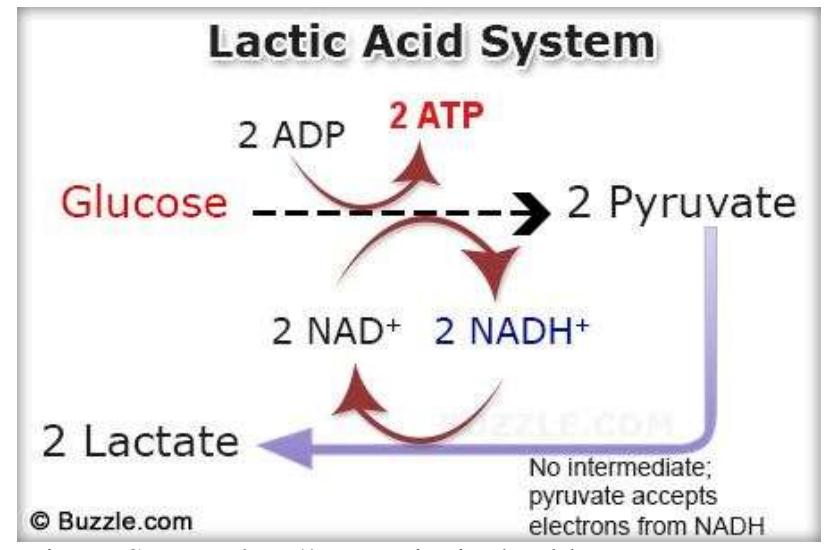

Figure Source: http//www.vivajoyhealth.com

Figure 5. Lactic Acid System 
To increasing the lactic acid level in the blood, the composite of Lactic acid is formed by reaction of the lactic acid in the blood, and then the Lactic acid will follow the blood circulation immediately. With the result, ATP resynthesis will not be conformable with it use, so the consequences of it the athlete will be fatigue. The cause of fatigue may be due to acidity increase and interfere with the smooth running of enzymes which involved by energy transfer. However, it does not mean that the cumulating of lactic acid was useless. The accumulating of lactic acids will be stored inside of human body during severe physical activity, but after the availability of oxygen, the hydrogen which bonded to Lactic acid is taken up by NHDA, so it will oxidize. Then this lactic acid ready to be converted into pyruvate acid. Pyruvate acid that has been rebuilt up can be used as a connector for the purposes of ATP energy resynthesis. At the time of recovery of an activity, pyruvate acid is converted into glycogen which stored in the liver.

Anaerobic glycolysis process can be summarized as follows: (1) the end result of anaerobic glycolysis is the formation of Lactic acid, and Lactic acid causes muscle fatigue, (2) anaerobic gilphololysis occurs without $\mathrm{O}_{2}$, (3) anaerobic glycolysis uses carbohydrates only; and (4) the energy released is just enough to reform some ATP molecules.

3) Aerobic System

At the end of the anaerobic system, glucose will be energized by oxygen aided. This system consists of two parts, namely: 1) a carbohydrate oxidation, and 2) fatty oxidation. When the supply of oxygen was enough, pyruvate acid is created. Most pyruvate acid enters into mitochondria through dehydrogenase. Then, glucose will be broken down into $\mathrm{CO} 2$ and $\mathrm{H} 20$. The process of reactions in muscle cells is described as follows:

$\mathrm{C}_{6} \mathrm{H}_{12} \mathrm{O}_{6}+6 \mathrm{O}_{2}-6 \mathrm{H}_{2} \mathrm{O}_{2}+6 \mathrm{CO}_{2}+$ Energy

Energy+39 ADP+39 Pi $-39 \mathrm{ATP}$

In oxygen system presence, it impedes the buildup of lactic acid but does not impede to ATP formation.

Referring to the three systems explained above, the anaerobic systems classified by basic on ATP-PC system and lactic acid system. Both systems are used in sports activities that require strength as at doing a forehand drive stroke on tennis.

\section{Conclusion}

In summary, the arm muscle power of a tennis athlete is influenced by the continuous training pattern of arm muscle strength with the proper dose and discipline of the athlete himself. A forehand drive movement on tennis is an anatomically combined of posterior extension-abduction movement. At doing of forehand drive, the most contracting muscle focused in arm muscle because the arm function to holds the racket. When the ball hits with full power it is proper a faster and sharper ball motion. Thus the arm muscle strength is very important to forehand drive stroke on tennis. In line with this, the ability measurement of a forehand drive stroke of athlete (subject) obtained through the score of point and value from the maximum results made by the subject on forehand stroke. Subject has ten times chances to do strokes, each ball must pass between the net and the rope line which stretched over one meter from the net and the ball shots to opponent court area which already shown scores. Ranging of the scores is $1-5$ for a point in the precision area and $1-5$ for value at strength area. The highest result was 100 (number of points and values) and the lowest value was 0 (love). These are resulted by the ball accuracy reached on the target with point 5 and the distance of ball bounce reached on point 5 of the part of the tennis court as well.

Of the three systems are described as result and discussion, the classified anaerobic system is the ATP-PC system and lactic acid system. Both systems are used in tennis when hit by forehand drive stroke.

\section{Conflict of interest statement and funding sources}

The author declared that he has no competing interest. The study was financed by independent funding.

\section{Statement of authorship}

The author has a responsibility for the conception and design of the study. The author has approved the final article.

Acknowledgments

The author would like to thank the editor of the journal for their valuable time and advice.

Sawali, L. (2018). Arm muscle power and energy system measurement of forehand drive on tennis. International Research Journal of Engineering, IT \& Scientific Research, 4(4), 30-39. 


\section{References}

Bompa, T. O. (1994). Theory and metodology of training, the key to athletic performance 3rd ed. Lowa: Hunt Publising Company.

Budiyono, S. (2011). Anatomi Tubuh Manusia. Bekasi: Laskar Aksara.

Cadore, E. L., \& Izquierdo, M. (2018). Muscle Power Training: A Hallmark for Muscle Function Retaining in Frail Clinical Setting.

Farisa, D., Amir, N., \& Jafar, M. (2017). Evaluasi Kekuatan Otot Lengan Petani Kelapa Sawit Kecamatan Simpang Kanan Kabupaten Aceh Singkil. Jurnal Ilmiah Mahasiswa Pendidikan Jasmani, Kesehatan dan Rekreasi, 3(2).

Fox, E. L., Bowers, R. W., \& Foss, M. L. (1989). The physiological basis of physical education and athletics. William C Brown Pub.

Harsono, M. S., \& Drs, M. S. (1988). Coaching dan Aspek-aspek Psikologis dalam Coaching.

Hewitt, J. E. (1966). Hewitt's tennis achievement test. Research Quarterly. American Association for Health, Physical Education and Recreation, 37(2), 231-240.

Indahwati, N. (2015). Perkembangan \& Belajar Motorik. Hand Out). Surabaya: Unesa University Press.

Magethi, B. (1990). Tenis Para Bintang. Bandung: Pionir Jaya.

Miller, M. G., Herniman, J. J., Ricard, M. D., Cheatham, C. C., \& Michael, T. J. (2006). The effects of a 6-week plyometric training program on agility. Journal of sports science \& medicine, 5(3), 459.

Orlick, T. (1986). Psyching for sport: Mental training for athletes (Vol. 1). Champaign, Ill.: Leisure Press.

Pradana, A. R. (2012). Pusat Pelatihan dan Gelanggang Olahraga Tenis Berstandar Internasional di Yogyakarta(Doctoral dissertation, UAJY).

Russel, P., Mc Clenghan, B., \& Rotella, R. (1993). Dasar-dasar Ilmiah Kepelatihan Terjemahan oleh Drs.

Sajoto, T., Santos, M., Heremans, J. J., Shayegan, M., Heiblum, M., Weckwerth, M. V., \& Meirav, U. (1989). Use of superlattices to realize inverted GaAs/AlGaAs heterojunctions with low-temperature mobility of $2 \times 106 \mathrm{~cm} 2 / \mathrm{V}$ s. Applied physics letters, 54(9), 840-842.

Sawali, L. (2018). Drills forehand training strategy on the stroke of forehand drive ability in tennis. International Journal of Physical Sciences and Engineering (IJPSE), 2(2), 11-20.

Schmidt, R. A., \& Wrisberg, C. A. (2008). Motor learning and performance: A situation-based learning approach. Human kinetics.

Schoenfeld, B. J., Peterson, M. D., Ogborn, D., Contreras, B., \& Sonmez, G. T. (2015). Effects of low-vs. high-load resistance training on muscle strength and hypertrophy in well-trained men. The Journal of Strength \& Conditioning Research, 29(10), 2954-2963.

Sharkey, B. J. (2003). Kebugaran dan Kesehatan.(eridesmarini nasution. Terjemahan). Jakarta: PT Raja grafindo Persada. Buku asli di terbitkan tahun. 


\section{Biography of Author}

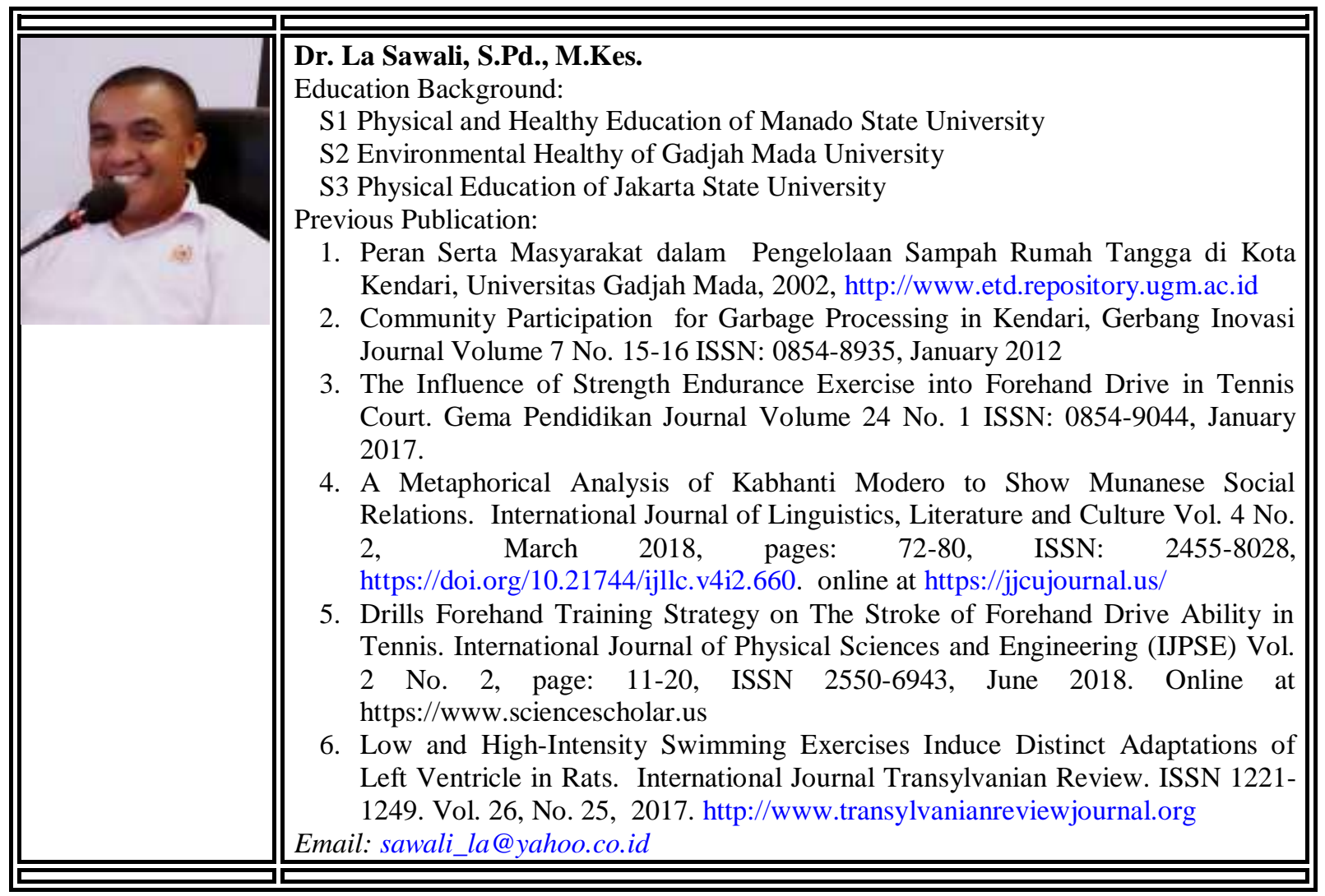

Sawali, L. (2018). Arm muscle power and energy system measurement of forehand drive on tennis. International Research Journal of Engineering, IT \& Scientific Research, 4(4), 30-39. https://doi.org/10.21744/irjeis.v4n4.259 